\title{
Brazilian Young Offenders: Profile and Risk Factors for Criminal Behavior
}

\author{
Alex Eduardo Gallo*
}

Departamento de Psicologia Geral e Análise do Comportamento / Centro de Ciências Biológicas, Mestrado em Análise do Comportamento, Universidade Estadual de Londrina Rod. Celso Garcia Cid, Km 380, CP: 10.011 - CEP: 86057-970 - Londrina, PR, Brazil

\begin{abstract}
This paper presents a study that belongs to a research program, driving at the development of adequate social repertoire, which could decrease offences by youth. Adolescents attended in community services and probation programs in a mid-size Brazilian city were characterized, under objective of assessing the major number of variables and its correlation to criminal behavior. Data were collected in a survey design and major results showed that: $87.8 \%$ were male, and age average was 15.9 years; about the offences, theft was the most common one (36.7\%) followed by robbery $(15.4 \%)$ and drug-dealing (9\%). Most of themwere not attending school and $61.8 \%$ had only the elementary degree. The results suggest that not attending school was associated to increasing number of re-incidences, use of drugs and use of weapons.
\end{abstract}

Keywords: Criminal behavior, demographic variables, risk factors.

Brazilian crime rateis expressively higher when compared to developed countries. Data from Brazilian Justice Ministry, published on 2011, collected from World Health Organization Statistical Information System (WHOSIS) reveal that homicide rate among adolescents is 59.2 per 100,000 inhabitants, compared to Finland (2.7), Canada (2.5), and Kyrgyzstan (3.1).

The Brazilian Constitution and the Estatuto da Criança e do Adolescente (Children and Adolescent Statute) consider the youth before age 18 adjudged to have committed delinquencies be dealt with not as offenders, but as being in a condition of delinquency and requiring help and guidance and supervision.

The ECA (Estatuto da Criança e do Adolescente) focuses on the responsibility of young person for consequences of their behavior. So, any adolescent who commits delinquent act is responsible for his/her action, including the criminal prosecution and sent for supervision as alternative measures. Table 1 presents the alternative measures applied in Brazil, according to the offences.

The Brazilian criminal justice system has these primary functions: investigation, laying of charges, prosecution, determination of guilt or innocence, sentencing and administration of the sentence. The criminal justice system consists of three interrelated parts that work together to protect society from the

\footnotetext{
*Address correspondence to this author at the Departamento de Psicologia Geral e Análise do Comportamento / Centro de Ciências Biológicas, Mestrado em Análise do Comportamento, Universidade Estadual de Londrina Rod. Celso Garcia Cid, Km 380, CP: 10.011 - CEP: 86057-970 - Londrina, PR, Brazil; E-mail: aedgallo@uel.br
}

moment a crime is committed until the offender is reintegrated into society. These parts are: policing, courts, and corrections. The system begins when adolescent is apprehended by police at the moment of a crime or after investigation. The police lay a charge and send to the court that can, based on evidences, decide for custody (until the end of investigation maximum of 5 days, or custody until end of hearing process - maximum of 45 days). The police has also the authority to divert the case from regular system when the severity allows it, not going to trial (ex, minor offences and victim does not want to go further into the system, police can send the offender to parents arguing about the consequences of a new offence).

In the court, once charges have been laid, the district attorney is responsible for deciding which charges the accused will face and for prosecuting those charges. If the adolescent has financial resources, he/she can hire a defense lawyer. If the accused does not have money to pay for a lawyer, the State set an ad hoc public defendant, guarantying the full defense principal. After the hearing, when the case proceeds to trial, the judge will decide whether the accused is guilty as charged. The Brazilian Criminal Code gives judges some leeway in their sentencing decisions, based on the principles that custody should be a last resort for the most serious offences, and not used if an effective alternative punishment is available.

After sentencing, the case is closed and transferred to correction department that is responsible for administer the sentences handed down by the judge, and determines when the sentence is completed. Each state is responsible for their corrections, except federal 
Table 1: Alternative Measures Applied in Brazil

\begin{tabular}{|c|c|}
\hline Measure & Definition \\
\hline Warning & Used as a pretrial measure to acknowledge the responsibility for the crime. It consists on verbal advertence. \\
\hline Repair the Damage & Restitution or financial compensation \\
\hline Community Services & $\begin{array}{l}\text { Service whereby the person performs a predetermined number of hours of volunteer community service work } \\
\text { to a non-profit agency (maximum of } 8 \text { hours a week, not exceeding } 6 \text { months) }\end{array}$ \\
\hline Probation & Minimum of 6 months and maximum of 3 years. \\
\hline Open Custody & Custody where the person has the right to attend school or job outside. \\
\hline Secure Custody & $\begin{array}{l}\text { Custody where the person has no right to attend activities out the facility. The person's performance under } \\
\text { this measure is evaluated every } 6 \text { months, not exceeding } 3 \text { years of custody. }\end{array}$ \\
\hline
\end{tabular}

corrections for major crimes, not applied to youth. Due some operational issues, the correction department can set cooperation contracts with non-profit agencies in cities where there is no facility for young offenders.

The applied alternative measure can, at any time, be extended, ended or replaced to another, after the judge accounts the adviser (the professional who follows the adolescent during the measure - probation officer), the district attorney and defense lawyer. The alternative measures could be applied after the trial or after a period of evaluation on secure custody. It means the person who is ending his/her sentence on secure custody could receive any other measure before full inclusion into society. However, secure custody could be applied as a regression, when the person who was sentenced to other measure failed to comply with the standards, is transferred to secure custody as a more severe measure for being unable to comply.

After sentencing, the offender is referred to correctional department and the professional working with the adolescent - the adviser (social workers and psychologists) applies an intake form. This intake form is part of a primary evaluation, followed by clinical interviews and reports.

Many studies examined different variables that could be linked to criminal behaviors. Some analyzed the influence of genetic factors (Brunner, Nelen, Breckfield, Ropers, \& van Oost, 1993; Christiansen, \& Knussmann, 1987; Dilalla, \& Gottesman, 1991; Loeber, \&Stouthamer-Loeber, 1998; Meddnick, Brenannan, \& Kandel, 1988; Renfrew, 1997); others examined poor academic performance, and low self-esteem (Joffe, Dobson, Fine, Marriage, \& Haley, 1990); or use of toxics (Renfrew, 1997; Stiffman, Earls, Dore, Cunningham, \& Farber, 1996). Some analyzed the influence of life experiences on criminal conduct, focusing on child sexual abuse, family relations and violent communities (Bandura, \& Iñesta, 1975; Jaffe, Wolfe, \& Wilson, 1990; Ropper, 1991; Schrepferman, \& Snyder, 2002).

Those variables can be called risk factors that are related to higher probability of negative results (Webster-Stratton, 1998). However, protective factors are those that modify or alter the personal response to environmental risk (Rutter, 1979). Risk factors can be divided into biological and environmental. It is important to consider that human behavior is not determined by a simple set of factors but multi-determined by complex relations among biological and environmental variables. So, the adolescent who presents criminal behaviors is someone exposed to different risk factors.

Risk factors can be divided into biological and environmental but it is important to consider that human behavior is not determined by simple set of factors but by complex relations among biological and environmental variables. So, the adolescents who break social rules are a person exposed to different risk factors. Gallo and Williams presented a summary of risk factors according to literature, that include learning problems and low academic achievement, family violence, violence on social relationships, abuse of drugs, and poverty.

All studies examined different risk factors but none related characteristics presented on young offenders profile to information about exposure to risk factors. This study characterized the young offenders profile, identifying variables associated to criminal behaviors.

\section{METHOD}

\section{Procedure}

We analyzed 123 (statistical sample) files of adolescents referred for alternative measures in a mid- 
size Brazilian city. Those files were elaborated by the advisor on alternative measures. The files were randomly accessed and contain the following documents:

1. Intake Form: interview with adolescent and his/her parents. This interview collects information about social-economic conditions, school and work conditions.

2. Charging and Prosecution: copy of police charge, copy of district attorney hearing, copy of previous records and alternative measure applied at that time.

3. Intervention Reports: psychotherapy, counseling and referrals reports were accessed only in cases when information from intake forms and charging and prosecution seemed to diverge.

\section{RESULTS}

Data obtained from file analysis showed that $87.8 \%$ of adolescents were male and age average was 15.9 years that are similar to data presented by Ministry of Justice report. Loeber and Stouthamer-Loeber (1998) pointed out that protective factors could act preventing girls to behave criminally. The Office for Juvenile Justice and Delinquency Prevention in Canada suggests that interventions should be gender specific because what would lead girls to behave criminally is different to boys (culture and gender expectations). The number of girls on alternative measures is smaller compared to boys (Cummings \& Leschied, 2002).

Among the sample, $75.6 \%$ were on probation and $24.4 \%$ on community services. Many of the adolescents were sentenced for the first time (82.9\%). Considering probation is more severe than community services, younger adolescents were sentenced to community services and severity of sentence increases as they get older, according to Loeber and StouthamerLoeber (1998) study.

Table 2 presents the compilation of offences recorded after prosecution and sentencing.

Theft was the most common crime (36.5\%), followed by robbery (15.4\%) and traffic of drugs (8.8\%). Comparing gender and crime, many female adolescents committed theft and traffic of drugs while boys were responsible for other offences. Offences that require direct contact to the victims (ex, robbery and assault) were committed by boys while those that does not require contact as possession of drugs, were committed by girls, what is similar to other studies (Loeber, \& Stouthamer-Loeber, 1998; Cummings, \& Leschied, 2002). Weapons were used on 23 offences $(44.5 \%$ were knives or similar and $55.5 \%$ were

Table 2: Offences Recorded After Prosecution and Sentencing

\begin{tabular}{|c|c|c|}
\hline Offences & Frequency & Percentage \\
\hline Theft & 45 & 36.5 \\
\hline Robbery & 19 & 15.4 \\
\hline Traffic of drugs & 11 & 8.8 \\
\hline Mischief & 10 & 8.1 \\
\hline Assault & 8 & 6.5 \\
\hline Possession of drugs & 6 & 4.9 \\
\hline Attempted theft & 4 & 3.2 \\
\hline Possession of stolen property & 4 & 3.2 \\
\hline Murder & 3 & 2.5 \\
\hline Utter threat & 2 & 1.7 \\
\hline Resist arrest & 3 & 2.5 \\
\hline Fraud & 3 & 2.5 \\
\hline Concealed weapon & 2 & 1.7 \\
\hline Rape & 2 & 1.7 \\
\hline Sexual offence & 1 & 0.8 \\
\hline Total & 123 & 100.0 \\
\hline
\end{tabular}




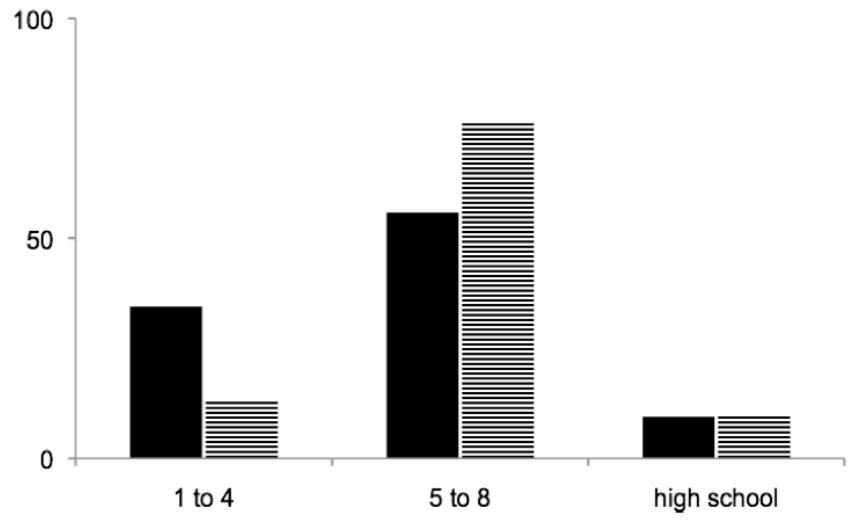

Figure 1: Percetage of adolescents on probation (dark bar) and community services (striped bar) according to school grade.

firearms). On contrary to what was expected, drug users were not the common (54.5\% did not use drugs). Among the users, marijuana was the most common (85.7\%).

About their families, $40.7 \%$ lived with both parents and $43.1 \%$ lived with a single mother $(2.4 \%$ lived with a single father and $13.8 \%$ lived with other responsible like grandparents). Single parent families suffer a more severe impact of several risk factors (American Psychological Association, 2003). Women, in many cases, heading of their families, deal with the stress to support family needs as well as parenting their children. It is important to point out that is not the only single parenting that could cause problem on child development but the relation this condition has to other risk variables, like mothers with low schooling (45.7\% had elementary degree) working on low qualification $\mathrm{e}$ income $(28.4 \%$ were cleaning workers) deal with a level of stress higher than those with a mate. This difficulty besides a poor network (lack of support, lack of community resources as daycare facilities, and others) could directly affect the parenting abilities.

The majority of adolescents in this study did not attend school (60.2\%). Among them, 43.2\% declared had dropped out due lack of interest. If we cluster other reasons presented (ex, school failure and conflicts) in a same category as problems school have dealing with those students, we have $76.9 \%$ of adolescents. Their educational level was very poor $(89.4 \%$ were on middle school) what is confirmed by other study (Patterson, DeBaryshe \& Ramsey, 1989). Young offenders have problems dealing with long term consequences, preferring immediate ones (Patterson, Reid \& Dishion, 1992) and attending school means deal with long term consequences and following rules behavior.

Figure 1 shows the relation between alternative measure and school degree. We can observe that adolescents who had lower academic degree (grade 4 or less) were on probation, while those with a higher educational level were on community services. This data confirms Kauffman (2001) when higher education could be a protective factor.

Table 3 presents the comparison between schoold attendance and use of drugs. Comparing school attendance and use of drugs, the results show that among adolescents attending school, $67.3 \%$ did not use drugs and when not attending school, the percentage of non users was 45.9. marijuana was the most common drug used by $47.3 \%$ of adolescentes not attending school and $26.5 \%$ of those on classes. This data supports that attending school could be a protecive factor for use of substances (Kauffman, 2001; Rutter, 1979).

Figure 2 points out the relation between school attendance and use of weapons. Weapons were mainly used by youngs who did not attend school but there was not relation between schooling and the type of weapon. Again, school attendance could be a protective factor (Garmezy, 1985).

\section{DISCUSSION}

This study is part of a research program aiming at the development of social repertoires that could contribute to reduce criminal behaviors. The study

Table 3: Frequency to School for Adolescentes Distributed According to Use of Drugs

\begin{tabular}{|c|c|c|c|c|}
\hline & \multicolumn{2}{|c|}{ Attending } & \multicolumn{2}{c|}{ Not Attending } \\
\hline Drug & Frequency & Percentage & Frequency & Percentage \\
\hline \hline Did not use & 33 & 67.3 & 34 & 45.9 \\
\hline Marijuana & 13 & 26.5 & 35 & 27.3 \\
\hline Cocaine & 1 & 2.1 & 3 & 4.1 \\
\hline Crack & 2 & 4.1 & 74 & 100.0 \\
\hline Total & 49 & 100.0 & 3 & \\
\hline
\end{tabular}




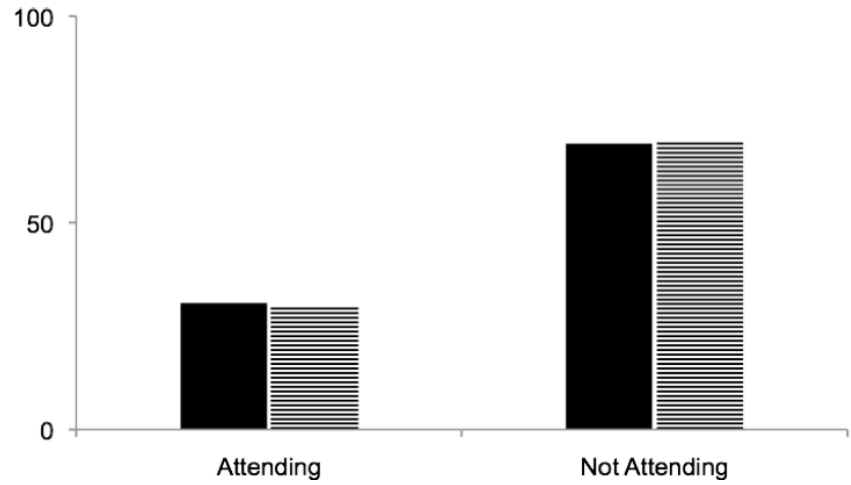

Figure 2: Percentage of adolescents that attended and not attended school, distributed according the use of firearms (dark bar) and knives (striped bar).

characterized adolescents attending alternative measures as probation and community services in a mid-size Brazilian city to identify variables associated to criminal behaviors. In synthesis, $69.9 \%$ of adolescents on alternative measures were born in the same city; $87.8 \%$ were male and $12.2 \%$ were female; age average was $15.9 \% ; 75.6 \%$ were on probation and $24.4 \%$ on community services; $82.9 \%$ was sentenced for the first time. Among the crimes, theft was the most common $(36.5 \%)$ followed by robbery $(15.4 \%)$ and traffic of drugs $(8.8 \%) ; 60.2 \%$ did not attend school, and among those, $43.2 \%$ dropped out due lack of interest; $89.4 \%$ were on middle school; $40.7 \%$ lived with both parents and $43.1 \%$ lived with a single mother; mothers studied on average 4.52 years and fathers $4.99 ; 28.4 \%$ of mothers were cleaning workers; $54.4 \%$ of adolescents did not use drugs and among users, $85.8 \%$ used marijuana.

The majority of participants did not attend school. Not attending school, described on literature as a possible risk factor, was associated, in the present study, to increasing number of re-incidences, use of drugs and weapons. The opposite was also verified: when attending school was compared to use of drugs and weapon, among adolescents attending school, the use of drugs was lower as the use of weapons. Moreover, the low educational level was against the higher one on severity of offences. This is to say that participants who had lower educational levels were on a more restricted measure.

Data suggests, in general, that offences are not so severe according to the type of measures applied. Community services, despite being a less severe measure, seems to be useful because created to the adolescent a social and professional environment, and with properly support he/she can learn to socialize, a job and social repertoires.
The study also found that higher educational level participants lived with both parents while those with lower levels lived with a single mother. Monoparental families, possibly, deal with a higher stress level, perhaps due the combination of low income and lack of support.

Major problem schools face on dealing with young offenders is disruptive behaviors that could lead to adoption of coercive discipline that could lead to school dropout. Brazilian teacher is not professionally prepared and do not have motivation to deal with this population. The lack of training to deal with young offenders and a not satisfied income are common issues on educational boards in Brazil.

\section{REFERENCES}

American Psychological Association (2003)."Advocate: The child, Youth, and Family Services". Bulletin of Division 37. Washington, DC: Authors.

Bandura, A., \& Iñesta, E. R. (1975). "Modificación de Conducta: Análisis de la Agresión y la Delincuencia". México: Trillas.

Brunner, H. G., Nelen, M., Breakfield, X. O., Ropers, H., \& van Oost, B. A. (1993). "Abnormal Behavior Associated with a Point Mutation in the Structural Gene for Monoamine Oxidase A". Science, 262, 578-580. http://dx.doi.org/10.1126/science.8211186

Christiansen, K., \& Knussmann, R. (1987). "Androgen Levels and Components of Aggressive Behavior in Men". Hormones and Behavior, 21, 170-180. http://dx.doi.org/10.1016/0018-506X(87)90042-0

Cummings, A. L., \& Leschied, A. W. (2002). "Research and Treatment for Aggression with Adolescent Girls: Mellen Studies in Social Work". Toronto: Edwin Mellen Press.

Dilalla, J. A., \& Gottesman, I. (1991). "Biological and Genetic Contributors to Violence: Widom's Untold Tale". Psychological Bulletin, 109, 125-129. http://dx.doi.org/10.1037/0033-2909.109.1.125

Garmezy, N. (1985). "Stress resistant children: The Search for Protective Factors". In J. Stevenson (Ed.). Recent Research in Developmental Psychology. Oxford: Pergamon Press.

Jaffe, P. G., Wolfe, D. A., \& Wilson, S. K. (1990). Children of Battered Women. Newburry Park, CA: SAGE Publications.

Joffe, R. D., Dobson, K., Fine, S., Marriage, K., \& Haley, G. (1990). "Social Problem-solving in Depressed, Conduct Disordered, and Normal Adolescents". Journal of Abnormal Psychology, 18(5), 565-575. http://dx.doi.org/10.1007/BF00911108

Kauffman, J. M. (2001). "Characteristics of Emotional and Behavioral Disorders of Children and Youth". Upper Saddle River, NJ: Merrill Prentice Hall.

Loeber, R., \& Stouthamer-Loeber, M. (1998). "Development of Juvenile Aggression and Violence: Some Common Misconceptions and Controversies". American Psychologist, 53(2), 242-259. http://dx.doi.org/10.1037/0003-066X.53.2.242

Meddnick, S. A., Brenannan, P., \& Kandel, E. (1988). "Predisposition to Violence". Aggressive Behavior, 14, 25-33. http://dx.doi.org/10.1002/1098-2337(1988)14:1<25::AIDAB2480140105>3.0.CO;2-9

Patterson, G. R., DeBaryshe, B. D., \& Ramsey, E. (1989). "A developmental Perspective on Antisocial Behavior". American Psychologist, 44(2), available on www.scielo.org. http://dx.doi.org/10.1037/0003-066X.44.2.329 
Patterson, G. R., Reid, J. B., \& Dishion, T. J. (1992). "Antisocial Boys". Eugene, OR: Castalia Publishing Company.

Renfrew, J. W. (1997). "Aggression and its Causes: A Biopsychosocial Approach". New York: Oxford University Press.

Ropper, W. L. (1991). "Prevention of Minor Young Violence Must Begin Despite Risk and Imperfect Understanding". Public Health Report, 106, 229-231.

Rutter, M. (1979). "Protective Factors in Children's Response to Stress and Disadvantage". In M. W. Kent \& J. E. Rolf (Eds.). Primary Prevention of Psychopathology: Social Competence in Children (p. 49-74). Hanover, NH: University Press of New England.
Schrepferman, L., \& Snyder, J. (2002). "Coercion: The Link Between Treatment Mechanisms in Behavioral Parent Training and Risk Reduction in Child Antisocial Behavior". Behavior Therapy, 33, 339-359.

http://dx.doi.org/10.1016/S0005-7894(02)80032-6

Stiffman, A. R., Earls, F., Dore, P., Cunningham, R., \& Farber, S. (1996). "Adolescent Violence".In R. DiClemente, W. Hanson \& L. Ponton (Ed.). Handbook of Adolescents' Health Risk Behavior (p. 289-312). New York: Plenum.

Webster-Stratton, C. (1998). "Early Intervention for Families of Preschool Children with Conduct Problems". In M. J. Guralnick (Ed.). The Effectiveness of Early Intervention (p.429-455). Baltimore: Paul H. Brookes Publishing.

Received on 27-02-2013

Accepted on 18-04-2013

Published on 30-04-2013

DOI: http://dx.doi.org/10.6000/1929-4409.2013.02.16

(c) 2013 Alex Eduardo Gallo; Licensee Lifescience Global.

This is an open access article licensed under the terms of the Creative Commons Attribution Non-Commercial License (http://creativecommons.org/licenses/by-nc/3.0/) which permits unrestricted, non-commercial use, distribution and reproduction in any medium, provided the work is properly cited. 